\title{
A 27-YEAR-OLD PATIENT WITH CONGENITAL BLADDER EXSTROPHY AND RECURRENT PELVIC ORGAN PROLAPSE: A CASE REPORT
}

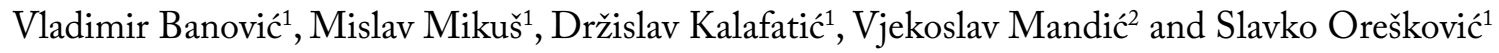 \\ ${ }^{1}$ Zagreb University Hospital Centre, Department of Obstetrics and Gynecology, Zagreb, Croatia; \\ ${ }^{2}$ Mostar University Hospital, Department of Obstetrics and Gynecology, Mostar, Bosnia and Herzegovina
}

\begin{abstract}
SUMMARY - Bladder exstrophy (BE) is a rare congenital malformation estimated to occur in up to $1 / 250,000$ female live births. The evidence supporting the incidence, uterine preservation and its overall fertility rate in patients with pelvic organ prolapse (POP) and $\mathrm{BE}$ is not precisely determined. We report a case of $\mathrm{BE}$ and POP in a 27-year-old nulliparous Caucasian. Due to the patient's strong fertility desire, considering her extensive surgical history background, our approach was to correct POP via the Manchester-Fothergill procedure. After 36 months, the patient was still asymptomatic with no evidence for prolapse recurrence. This case demonstrates diagnostic challenges and surgical dilemmas in treatment strategy for patients with $\mathrm{BE}$ and co-existent POP. Furthermore, routine longterm surveillance is necessary in terms of renal function, urinary continence, malignancy and possible obstetric issues.
\end{abstract}

Key words: Bladder exstrophy; Pelvic organ prolapse; Pregnancy; Manchester-Fothergill procedure

\section{Introduction}

Bladder exstrophy $(\mathrm{BE})$ is a rare congenital malformation characterized by eversion of the bladder through the anterior abdominal wall, often accompanied with pubic diastasis, bifid clitoris, anteriorly displaced vagina and anus, and anomalies outside the genitourinary system such as omphalocele, neural tube and skeletal defects $^{1}$. This condition is estimated to occur in up to $1 / 250,000$ female live births ${ }^{1}$. The evidence supporting the incidence, uterine preservation and its overall fertility rate in patients with pelvic organ prolapse (POP) and $\mathrm{BE}$ is controversial, since clinical outcomes in this remarkable setting have not been exactly outlined. We report a case of BE in a 27-year-old nulliparous Caucasian with the aim to complement the overall knowledge on this quite uncommon female cohort.

Correspondence to: Držislav Kalafatiç, $M D, P h D$, Department of Obstetrics and Gynecology, Zagreb University Hospital Centre, Petrova 13, HR-10000 Zagreb, Croatia

E-mail: drzislav.kalafatic12345@gmail.com

Received December 2, 2019, accepted March 10, 2020

\section{Case Report}

A 27-year-old patient was referred to our Department with discomfort in perianal region, incomplete voiding, dyspareunia, and apparent genital prolapse. She had a history of congenital BE associated with pubic bone agenesis. There was no family history of exstrophy or other congenital anomalies. Her past surgical history was considerable and included multiple reconstructive surgical procedures. The initial surgical procedure was performed 48 hours after birth. The patient underwent complete primary closure of the anterior abdominal wall in the form of bladder preservation while internal diversion of the urine was obtained through a sigmoid reservoir, with satisfactory continence achieved. At the age of 18 , suffering from a severe uterine prolapse, the patient underwent transvaginal bilateral sacrospinous hysteropexy using Prolift $+\mathrm{M}$ system (Gynecare/Ethicon, Somerville, NJ, USA). Three years later, severe POP reappeared. Due to complicated surgical history, sacral hysteropexy per laparotomy using Prolene mesh was performed. In the pe- 


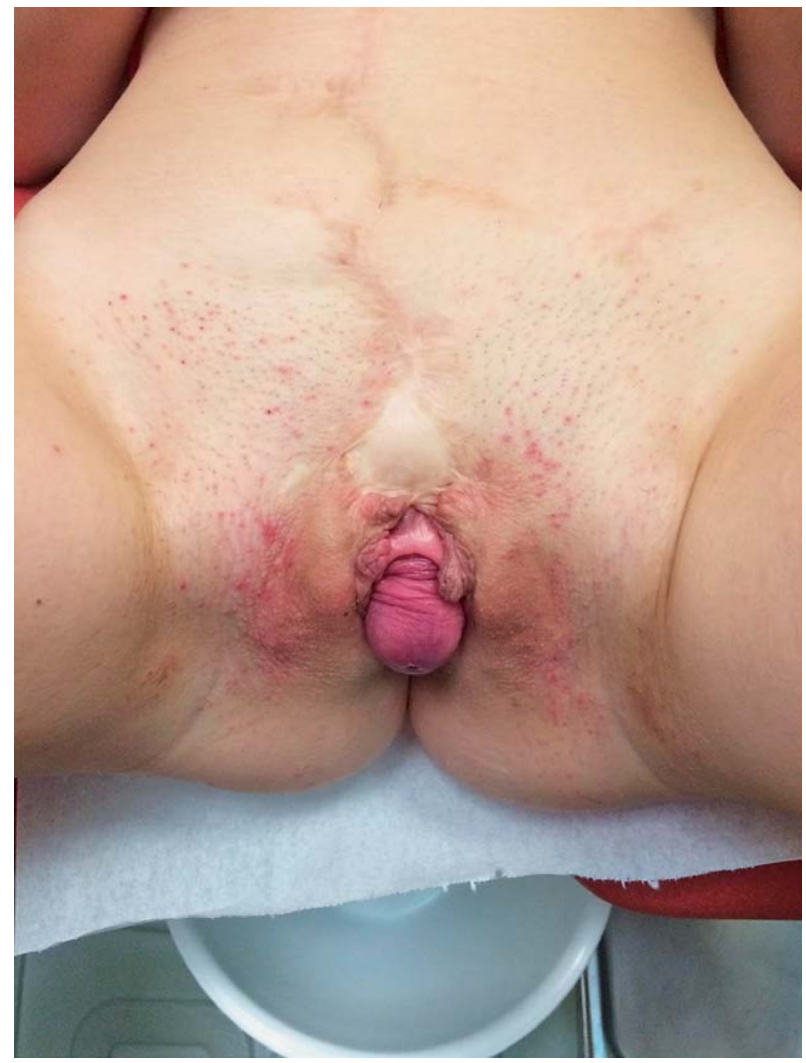

Fig. 1. Physical examination at the time of presentation.

riod between these two procedures she was hospitalized because of sepsis, losing 10 kilograms in a short period of time, with subsequent amenorrhea.

Physical examination at the time of presentation for suspected recurrent prolapse revealed pelvic diastasis of roughly 5-6 cm while the entire anatomy of the vulval region was deformed due to absent symphysis pubis and scars from previous surgical procedures (Fig. 1). Her cervical tissue was tumefied as a result of menstrual cycles. According to the Pelvic Organ Prolapse Quantification system (POP-Q), her C point was at the level +2 and $\mathrm{D}$ point at the level -4 , thus indicating cervical length of $6 \mathrm{~cm}$.

Due to the patient's strong fertility desire, considering her extensive surgical history background, our approach was to correct POP via the ManchesterFothergill procedure (MFP). Institutional review board approval was not required as the patient was treated with the approved diagnostic and therapeutic procedure according to the generally accepted standards of care. Thus, we only obtained a signed consent form from the patient. MFP begins with circumferen- tial incision of the cervix and mobilizing the bladder and the vagina off the cervix and cardinal ligaments. After isolation of the cervix, amputation was performed using diathermy. The remaining uterus was suspended with the cardinal ligaments on the anterior side of the shortened and reconstructed cervix using an absorbable polyfilament polyglactin 910 (1-0 Vicryl $^{\oplus}$, Ethicon, USA) suture.

After 36 months, the patient was still asymptomatic with no evidence for prolapse recurrence. According to $\mathrm{POP}-\mathrm{Q}, \mathrm{C}$ point was at the level -5 and $\mathrm{D}$ point at the level -7 , with calculated cervical length of $2 \mathrm{~cm}$. The patient had regular menstrual cycles, although she did not achieve pregnancy by the time of writing this report.

\section{Discussion}

This report describes our clinical experience with MFP for the treatment of recurrent POP in a young nulliparous patient with congenital $\mathrm{BE}$. This particular female population is surgery-prone; these patients on average undergo nine pelvic procedures, up to $52 \%$ of them are suffering from POP, contradictory appearing in their younger age and often independent of parity ${ }^{1}$. Current evidence suggests that congenitally weakened cardinal and uterosacral ligaments along with pubic diastasis and damaged anatomical aspects of levator ani muscles are contributing to subsequent $\mathrm{POP}$ in women with $\mathrm{BE}^{2,3}$. Since it affects women in their reproductive age, the main concern is balance between their future fertility crave and overall quality of life.

Pelvic organ prolapse may be treated by several surgical approaches, including vaginal and abdominal route, with no consensus regarding which technique is better ${ }^{1}$. According to recently published data, there is a lower reoperation rate due to symptomatic POP recurrence in MFP compared to vaginal hysterectomy (VH) (5-year reoperation rate of 2.8\% after MFP vs. $13 \%$ after $\mathrm{VH})^{4,5}$. Furthermore, compared to $\mathrm{VH}$, MFP is a less extensive procedure requiring minimal dissection and shorter operating time, associated with less blood loss, lower risk of intraoperative complications and subsequently shorter hospitalization ${ }^{4,5}$. Park et al. found that in the MF operation group, postoperative bleeding and cervical stenosis were major complications, whereas the most common postoperative complication in the $\mathrm{VH}$ group was postoperative in- 
fection ${ }^{6}$. When performing uterine-preservation procedures such as MFP, we have to consider an inherent risk of future uterine pathologic conditions. If we consider the importance of uterus and sacrospinous-cardinal ligament complex in pelvic floor support, there is no justification for uterine removal because of the potential uterine pathology $y^{4}$

Preoperatively performed POP staging according to $\mathrm{POP}-\mathrm{Q}$ suggested recurrent apical prolapse, with no clear determination between uterine descent from cervical elongation. In this particular case, the anatomical changes, potential adhesions after multiple surgical procedures and the overall insufficiency of available diagnostic and clinical assessment tools made the operative management demanding. We assumed a lack of uterine mobility due to the adhesions from previous surgical procedures. Our clinical interpretation was that cervical elongation occurred after sacral hysteropexy, thus mimicking uterine prolapse recurrence. Furthermore, we considered $\mathrm{BE}$ as an independent risk factor for cervical elongation, as previously described by Kwong et al. ${ }^{2}$. Hypertrophic elongation of the cervix in our patient may also be a result of tissue reaction to previous incorporation of synthetic mesh ${ }^{7}$.

On selecting appropriate surgical management, every attempt should be made to preserve fertility, but also to avoid scarring, which may lead to vaginal stenosis and dyspareunia. If MFP is performed in the appropriate group of patients who present with true cervical elongation, the recurrence rate of genital prolapse is extremely low ${ }^{8}$.

Bladder exstrophy is associated with normal to mildly impaired fertility ${ }^{9}$, joined with the previous MFP. The pregnancy rate can be diminished to $33 \%$ with an increased risk of preterm delivery ${ }^{9}$. However, tight antenatal management, prophylactic cerclage and cesarean section must be considered ${ }^{9}$.

In conclusion, the management of $\mathrm{BE}$ has significantly improved in recent decades. This case demonstrates diagnostic challenges and surgical dilemmas in treatment strategy for patients with $\mathrm{BE}$ and co-existent POP. Furthermore, routine long-term surveillance is necessary in terms of renal function, urinary continence, prolapse recurrence ${ }^{10}$, malignancy ${ }^{11}$, and possible obstetric issues ${ }^{12}$.

\section{References}

1. Ferrer MLS, Sánchez EB, Hernández LH, Linde FM, Peñalver AIH, Díaz AN. The Manchester-Fothergill and the Elevate Posterior ${ }^{\circledR}$ technique for the correction of a cervical elongation and large enterocele in a patient with bladder exstrophy and multiple surgeries. Int Urogynecol J. 2015;26(8):1239-42. doi: 10.1007/s00192-014-2610-8

2. Kwong Y-TD, Knoepp LR, Wright EJ, Chen CCG. Recurrent pelvic organ prolapse in a patient with history of bladder exstrophy. Female Pelvic Med Reconstr Surg. 2012;18(1):61-3. doi: 10.1097/spv.0b013e31823bdbbe

3. Delancey J. Pelvic floor anatomy and pathology. Biomechanics of the Female Pelvic Floor. 2016;13-51. doi: 10.1016/b978-012-803228-2.00002-7

4. Walsh CE, Ow LL, Rajamaheswari N, Dwyer PL. The Manchester repair: an instructional video. Int Urogynecol J. 2017; 28(9):1425-7. doi: 10.1007/s00192-017-3284-9

5. Tolstrup CK, Lose G, Klarskov N. The Manchester procedure versus vaginal hysterectomy in the treatment of uterine prolapse: a review. Int Urogynecol J. 2016;28(1):33-40. doi: 10.1007/s00192-016-3100-y

6. Park YJ, Kong MK, Lee J, Kim EH, Bai SW. Manchester operation: an effective treatment for uterine prolapse caused by true cervical elongation. Yonsei Med J. 2019;60(11):1074. doi: 10.3349/ymj.2019.60.11.1074

7. Hyakutake MT, Cundiff GW, Geoffrion R. Cervical elongation following sacrospinous hysteropexy: a case series. Int Urogynecol J. 2013;25(6):851-4. doi: 10.1007/s00192-013-2258-9

8. Boer TAD, Milani AL, Kluivers KB, Withagen MIJ, Vierhout $\mathrm{ME}$. The effectiveness of surgical correction of uterine prolapse: cervical amputation with uterosacral ligament plication (modified Manchester) versus vaginal hysterectomy with high uterosacral ligament plication. Int Urogynecol J. 2009;20(11):13139. doi: 10.1007/s00192-009-0945-3

9. Kaufman MR. Pelvic organ prolapse and pregnancy in the female bladder exstrophy patient. Curr Urol Rep. 2018;19(3). doi: 10.1007/s11934-018-0767-2

10. Ridgeway BM. Does prolapse equal hysterectomy? The role of uterine conservation in women with uterovaginal prolapse. Am J Obstet Gynecol. 2015;213(6):802-9. doi: 10.1016/j.ajog. 2015.07.035

11. Smeulders N, Woodhouse C. Neoplasia in adult exstrophy patients. BJU Int. 2002;87(7):623-8. doi: 10.1046/j.1464-410x. 2001.02136.x

12. Wu S, Sun J, Lv H, Zhang Y, Shang H, Zhang H, et al. Pregnancy in a woman with untreated bladder exstrophy: a case report. Case Rep Womens Health. 2018;17:11-3. doi: 10.1016/j. crwh.2018.02.002 


\section{Sažetak \\ RECIDIVIRAJUĆI PROLAPS ZDJELIČNIH ORGANA KOD 27-GODIŠNJE BOLESNICE S PRIROĐENOM EKSTROFIJOM MOKRAĆNOG MJEHURA: PRIKAZ SLUČAJA}

\section{Banovic, M. Mikuš, D. Kalafatic, V. Mandić i S. Orešković}

Ekstrofija mokraćnog mjehura je rijetka prirođena malformacija za koju se procjenjuje da se javlja u do 1/250.000 ženske novorođenčadi. Prema trenutnim literaturnim navodima imamo nedovoljno podataka o incidenciji i ukupnoj reproduktivnoj sposobnosti žena koje istodobno uz ekstrofiju mokraćnog mjehura imaju i prolaps zdjeličnih organa. Prikaz slučaja obuhvaća naše iskustvo liječenja 27-godišnje bolesnice s prirođenom ekstrofijom mokraćnog mjehura i recidivirajućim prolapsom zdjeličnih organa. S obzirom na snažnu želju bolesnice za očuvanjem plodnosti te uzimajući u obzir njezinu opsežnu kiruršku povijest, naš pristup je podrazumijevao ispravak prolapsa zdjeličnih organa pomoću operacije po Manchester-Fothergillu. Nakon 36 mjeseci bolesnica je i dalje bez simptoma te bez ikakvih kliničkih dokaza recidiva prolapsa. Ovaj slučaj naglašava dijagnostičke izazove i kirurške dileme u strategiji liječenja bolesnica s ekstrofijom mokraćnog mjehura i istodobnom pojavom prolapsa zdjeličnih organa. Također, važno je naglasiti dugotrajno rutinsko praćenje u vidu kasnije bubrežne funkcije, moguće inkontinencije mokraće, maligniteta i mogućih opstetričkih komplikacija.

Ključne riječi: Ekstrofja mokraćnog mjehura; Prolaps zdjeličnih organa; Trudnoća; Operacija po Manchester-Fothergillu 